TITLE:

\title{
NEW AND RARE COMMENSAL PEDUNCULATE CIRRIPEDS FROM AMAKUSA ISLANDS, WESTERN KYUSYU, JAPAN
}

\author{
$\operatorname{AUTHOR}(\mathrm{S})$ : \\ Utinomi, Huzio
}

\section{CITATION:}

Utinomi, Huzio. NEW AND RARE COMMENSAL PEDUNCULATE CIRRIPEDS FROM AMAKUSA ISLANDS, WESTERN KYUSYU, JAPAN. PUBLICATIONS OF THE SETO MARINE BIOLOGICAL LABORATORY 1970, 18(3): 157-167

ISSUE DATE:

1970-11-25

URL:

http://hdl.handle.net/2433/175633

RIGHT: 


\title{
NEW AND RARE COMMENSAL PEDUNCULATE CIRRIPEDS FROM AMAKUSA ISLANDS, WESTERN KYUSYU, JAPAN ${ }^{1) 2}$
}

\author{
Huzio UTINOMI \\ Seto Marine Biological Laboratory
}

With 9 Text-figures

\section{Introduction}

Formerly I have enumerated 52 species of Thoracican cirripeds, occurring in the environs of the Amakusa Islands, with an ecological note as a guide for collecting by Dr. Taiji Kiкuchi of the Amakusa Marine Biological Laboratory (Utinomi, 1962; Utinomi and KikUCHI, 1966).

Very recently, Mr. Akio TAKr, who was then a staff member of the Amakusa Marine Biological Laboratory, has collected two interesting pedunculate cirripeds commensal with other benthic animals with trammel nets, called locally as "Kasiami" and provided me with all specimens for identification. Subsequent examination revealed that one of them was an undescribed species of the scalpellid genus Calantica (Calantica) Gray and the other was referable to Pagurolepas conchicola STubBings which has not been ever recorded since it was originally described from John Murray Expedition Station 122, Zanzibar Area, East Africa.

So, the present paper deals with the detailed descriptions and illustrations that have been elucidated for these remarkable cirripeds, as a supplement to the known faunal list around the Amakusa Islands.

Before going further, I wish to express my hearty thanks to Mr. Akio TAKI (now at the Zoological Institute of Kyoto University) for offering these interesting specimens, together with color transparencies of them in the living state, either as attached to their hosts or solitarily. My thanks are also due to Dr. Saburo Nishimura of our Laboratory for the help in photographing the specimens.

1) Contributions from the Amakusa Marine Biological Laboratory, Kyushu University, No. 216.

2) Contributions from the Seto Marine Biological Laboratory, No. 524.

This study was supported in part by a grant for Scientific Research from the Ministry of Education, \#84089 (in 1969).

Publ. Seto Mar. Biol. Lab., XVIII (3), 157-167, 1970. (Article 11) 


\section{Descriptions}

\section{Calantica (Calantica) pusilla, n. sp.}

New Japanese Name: Hime-hanamyôga

(Figs. 1-4)

Material Examined.-Three specimens attached to small terminal branches of a living Paramuriceid gorgonacean Anthogorgia bocki Aurrvilurus. Obtained by Mr. Akio TAKI at Tomioka, Amakusa Islands at a depth of 25-30 fathoms, on 19th April, 1967.

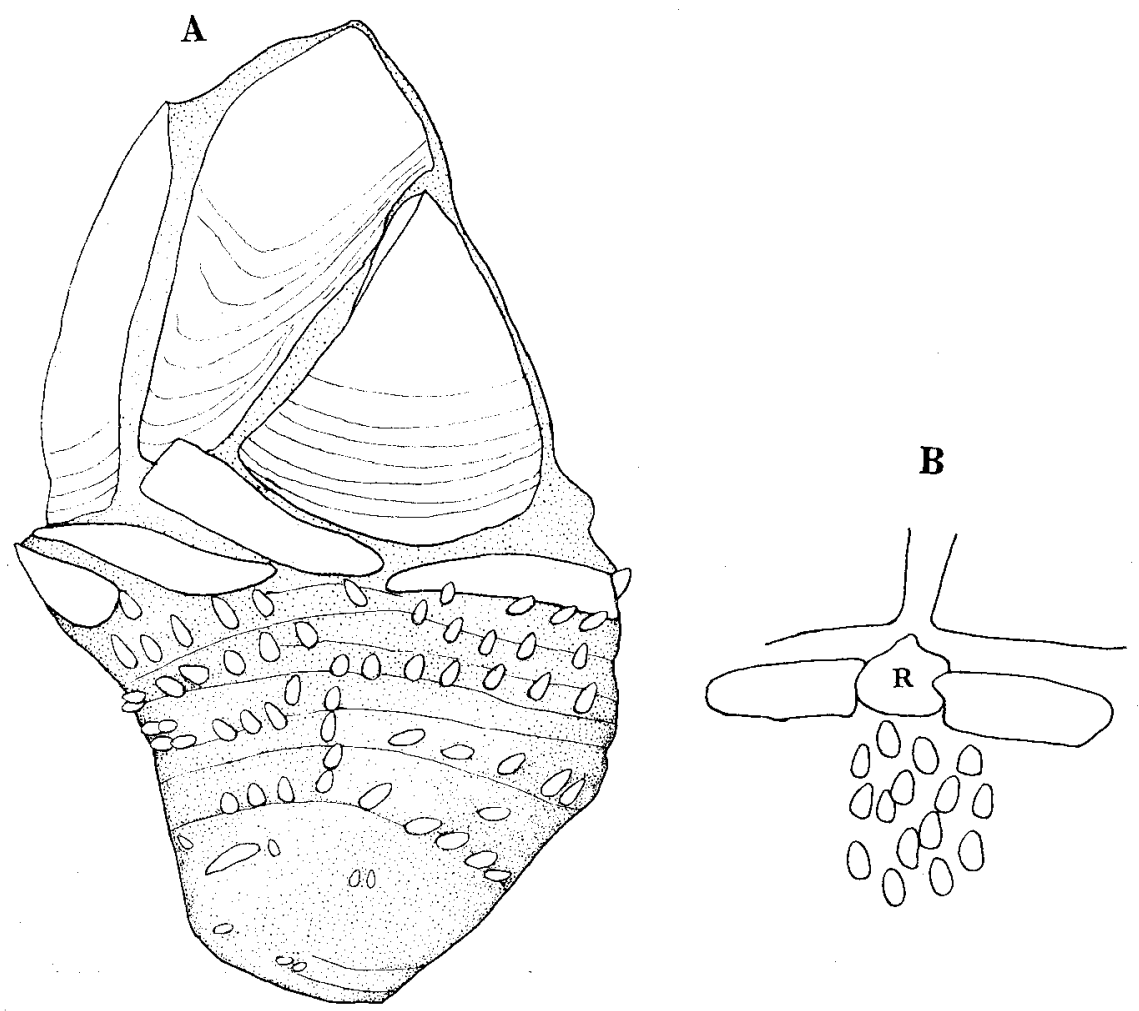

Fig. 1. Calantica (Calantica) pusilla, n. sp.

A, Holotype in side view, showing the arrangement of capitular valves and peduncular scales. $\times 18$. B, surrounding part of rostrum (R) in Paratype A.

TyPes.-Holotype and 2 paratypes are deposited in the museum of the Seto Marine Biological Laboratory, registering as S.M.B.L. Type no. 233 (A, B and C).

Description.-The specimens (hermaphrodite) are comparatively small for the genus, being about 9-10 $\mathrm{mm}$ long and $4 \mathrm{~mm}$ wide. 
The capitulum is subtriangular, roundly tipped and slightly longer than the peduncle.

Each valve in the upper whorl is roundly or obtusely tipped, mostly grayish white but tinged with bright red pattern around the tip alive. Their surface is almost smooth, only marked concentrically with slight growth lines.

The scutum is quite triangular, though the basal margin is slightly convex (Fig. 2A).

The tergum is the largest and highest of all valves, wedge-shaped, more roundly angled at the tip than at the bottom and almost erect (Fig. 2B).

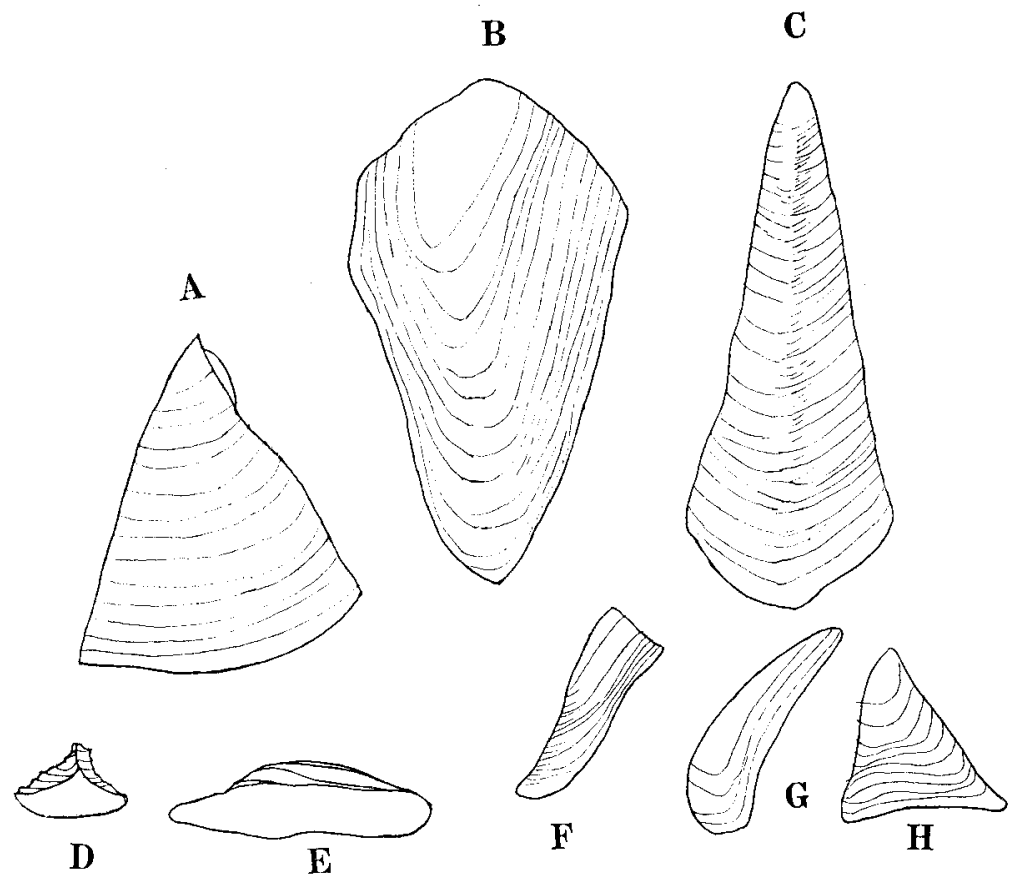

Fig. 2. Calantica (Calantica) pusilla, n. sp.

Details of capitular valves. $\times 12 . \mathrm{A}$, scutum; $\mathrm{B}$, tergum; C, carina; $\mathrm{D}$, rostrum; E, rostral latus; F, inframedian latus; G, carinal latus; $H$, subcarina. D and $\mathrm{E}$ are viewed from inside. The rest are viewed from outside.

The carina is narrowly triangular and placed dorsally, slightly incurving at the tip a little below the capitular tip (Fig. 2C).

These three upper valves are well separated, leaving narrow spaces.

In the lower whorl, however, all the valves are comparatively large and transversely arranged in a ring close to the upper margin of the peduncle.

Of the lower valves, the rostrum (Figs. $1 \mathrm{~B}$ and 2D) is the smallest, triangular and inserted between the rostral latus on both sides.

The rostral latus (Figs, $1 \mathrm{~B}$ and $2 \mathrm{E}$ ) is rectangular, wider than long. 
The inframedian latus (Fig. 2F) is elongate triangular or subrectangular, tapering rostralwards and obliquely placed between the scutum and carina at the bottom of the tergum.

The carinal latus (Fig. 2G) is somewhat lozenge-shaped, projecting slightly at the base of the carina.

The subcarina (Fig. 2H) is comparatively large, triangular and projects just below the tip of the carinal latus on both sides.

All these lower valves are very thin, semitransparent, bearing only indistinct growth lines, and uniformly pinkish white alive.

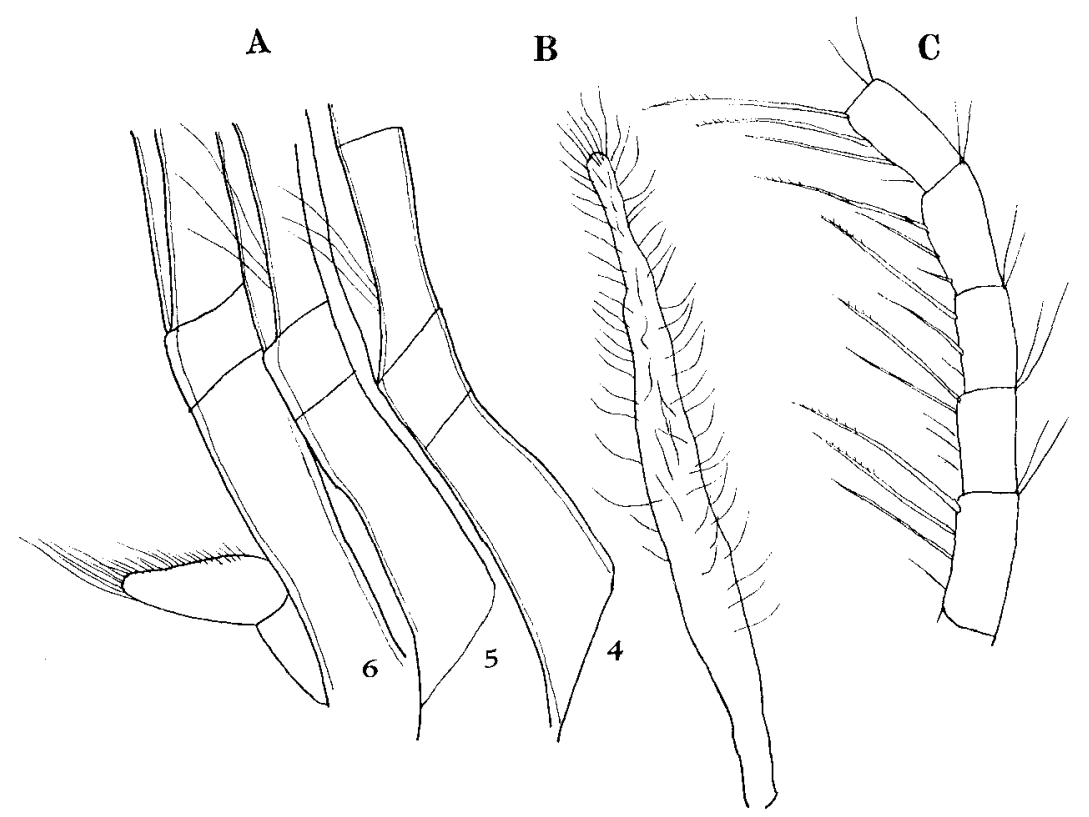

Fig. 3. Calantica (Calantica) pusilla, n. sp.

Bodial appendages. $\times 33$. A, basal part of posterior cirri (4th to 6 th), with a caudal appendage; $\mathrm{B}$, penis; $\mathrm{C}$, intermediate segments of the last cirrus.

The peduncle is a little shorter than the capitulum, subtriangular in lateral view and somewhat laterally compressed, and covered with many minute scales arranging in more than 6 transverse rows. These scales are rodlike and slightly imbedded in the thick cuticle wrinkled here and there.

No dwarf male was found in the usual position below the orifice.

The mouthparts are typical of the genus.

The cirri of the largest one (Paratype A) have the following number of segments in each cirrus.

$$
\overbrace{99}^{\mathrm{I}} \overbrace{12 \mathrm{1} 1}^{\mathrm{II}} \overbrace{111}^{\mathrm{III}} \overbrace{1111}^{\mathrm{IV}} \overbrace{12 \quad 14}^{\mathrm{V}} \overbrace{1515}^{\mathrm{VI}}
$$


The setation in each segment of the posterior cirri (Figs. 3A and 3C) is, as usual, of the ctenopod type, bearing 3-4 pairs of peculiar ventral setae which are fimbriate distally along the upper margin, like those in the unique scalpellid Pisiscalpellum withersi Utinomi (cf. Utinomi, 1958, p. 115, fig. 2, $h$-i). More interesting is that the posterior cirri bear a set of 3 long setae about midway along the dorsal side of the proximal segment of the anterior ramus (Fig. 3A).

The caudal appendage (Fig. 3A) is uniarticulate, very short and laterally flattened, armed with many setules on the frontal side and extremity.

The penis (Fig. 3B) is about $3 / 5$ as long as the last cirri, strongly hairy, but apparently dwindled and unannulated throughout the length.

Dimensions (in $\mathrm{mm}$ ).-

\begin{tabular}{lcccc} 
& \multicolumn{2}{c}{ Total size } & Length of capitulum & Length of peduncle \\
Holotype & 10 & 6 & 4 \\
(length) & 4 & (width) & 6.5 & 4 \\
Paratype A & 10.5 (length) & 6 & 4 \\
Paratype B & 6 & (width) & (length) &
\end{tabular}

Affinity.-In general appearance this species somewhat resembles Similium scorpio (Aurivillius, 1894) which is common in the East Asiatic continental waters,

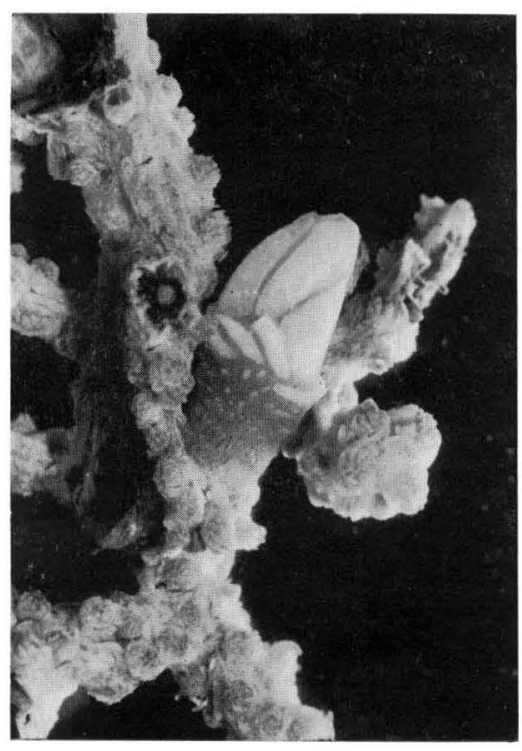

Fig. 4. Calantica (Calantica) pusilla, n. sp. Paratype B, attached to twigs of a gorgonacean Anthogorgia bocki AURIVILLIUS. $\times 3$ (approx.).

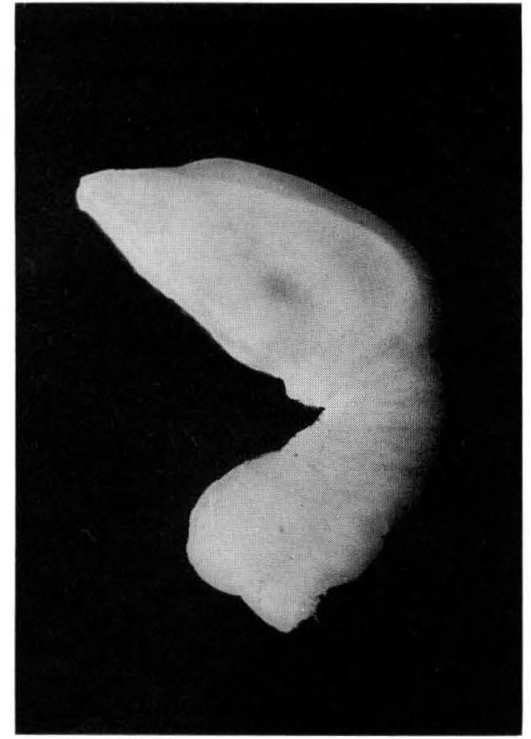

Fig. 5. Pagurolepas conchicola StubBings. Right side. $\times 3.2$ (approx.). 
but it is clearly characterized by its unusually small size and roseate coloration of the capitular valves in the upper whorl and the transversely or obliquely placed lateral valves in the lower whorl which are diversified in shape. In addition, the peculiarity in the setation found in the cirri is also noticeable. In view of the small size of the total animal, the comparatively developed lower lateral valves, the shortness of the peduncle and the peculiar setation of the cirri, this species seems to be closely related to the unique scalpellid Pisiscalpellum UTINOMI, 1958 rather than to the common genus Calantica Gray, 1825, including four subgenera Calantica s. str., Scillaelepas Seguenza, Titanolepas Withers and Paracalantica Utinomi, although the capitular architecture well coincides with that of Calantica s. str. (cf. Pilsbry, 1907; Hoek, 1907; Broch, 1922, 1931; Hiro, 1932; Utinomi, 1949; Newman et al., 1969).

Other Associate.- On this host gorgonacean Anthogorgia bocki Aurivillius, another peculiar polychaete commensal Haplosyllis anthogorgicola UTinomi occasionally inhabits also, forming tube-like outgrowths of the bark (UTіNomi, 1956).

\section{Pagurolepas conchicola STUBBINGS, 1940}

New Japanese Name: Yadokari-ebosi

(Figs. 5-9)

Material Examined.-A single specimen attached to the siphonal canal below the large pallial cavity of the gastropod shell Fusinus perplexus (A. Adams) inhabited by the hermit crab Dardanus diogenes (DE HAAN) by the expanded base of the peduncle. Obtained by Mr. Akio TAKI at Tomioka, Amakusa Islands at a depth of 35 fathoms, on 6th October, 1966. Now deposited in the museum of the Seto Marine Biological Laboratory, registering as S.M.B.L. Rare no. 255.

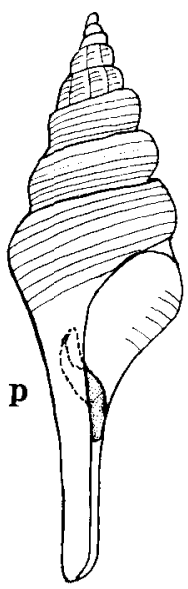

A

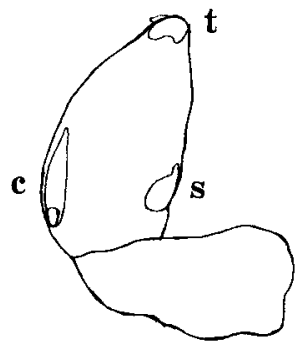

B
Fig. 6. Pagurolepas conchicola Stubbings. A, Natural posture of Pagurolepas (P) attached to the siphonal canal of the host gastropod shell Fusinus perplexus (A. Adams), drawn after Mr. A. TAKI's observation note while collecting alive. The hermit crab inhabited into the host shell is omitted. $B$, Rough sketch of the outer left side of the barnacle, showing only the well-calcified umbonal part of the $\operatorname{scutum}(\mathrm{s})$, tergum $(\mathrm{t})$ and carina $(\mathrm{c})$. $\times 2$ (approx.). 
Description.-Because of such a protected habitation a conspicuous distortion occurs on the growth of the mantle bearing protective plates which are usually symmetrical on both sides in normal cases. As a result of distortion, the capitular valves are asymmetrical, like an example of Poecilasma obliquum Hoek (cf. Hiro, 1937, pp. 408-412, fig. 8).

On the left side of the capitulum faced to the inner folding of the parietal wall

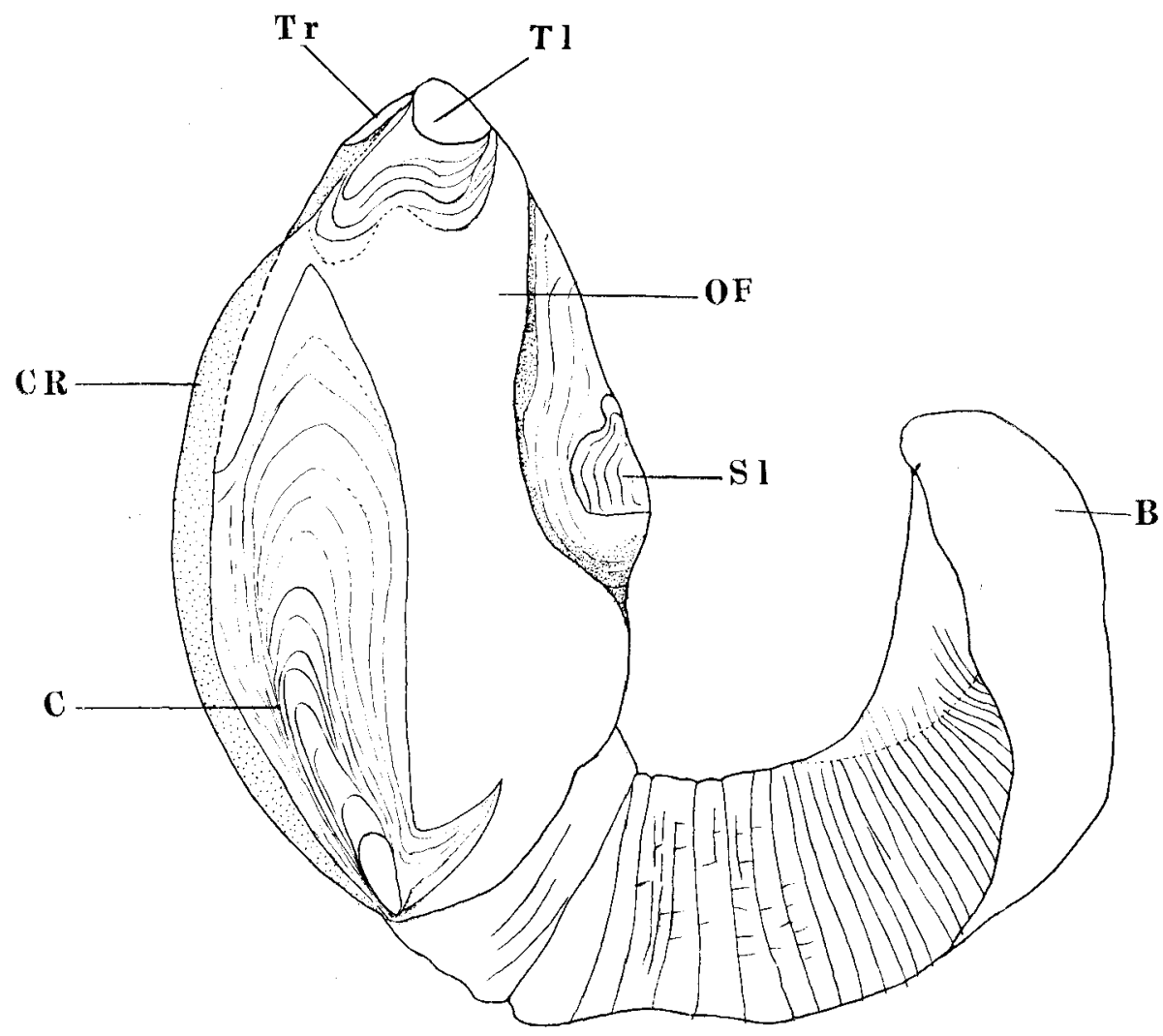

Fig. 7. Pagurolepas conchicola Stubrings. Outer left side.

$\mathrm{B}$, base of peduncle; $\mathrm{C}$, carina; $\mathrm{CR}$, carinal ridge; $\mathrm{OF}$, occludent folding of integument; $\mathrm{S} 1$, left scutum; T1, left tergum; Tr, right tergum. $\times 6.6$ (approx.).

of the shell nearest to the columella (Fig. 6A), the calcification of the valves is largely restricted to the umbonal area, so that the valves seem to be much reduced at a glance (cf. Fig. 6B and Stubbings' Text-fig. 1B). However, if examined in detail under high-power lens, it may be defined that the marginal area in each of the valves is not 'reduced' but in fact weakly calcified only on the left side. On this point compare the figures 7 and 8 . In every valve, the umbonal part is well calcified and quite 
white in dried state and smaller than the marginal part which is either dirty white or yellowish and thin, semitransparent.

The carina (Fig. 7, C) is located on the outer left side, separating a little from the real carinal border (Figs. 7 and 8, GR) where the integument is distinctly keeled. The carina itself is rather large, trifurcate in outline; on the left margin near the

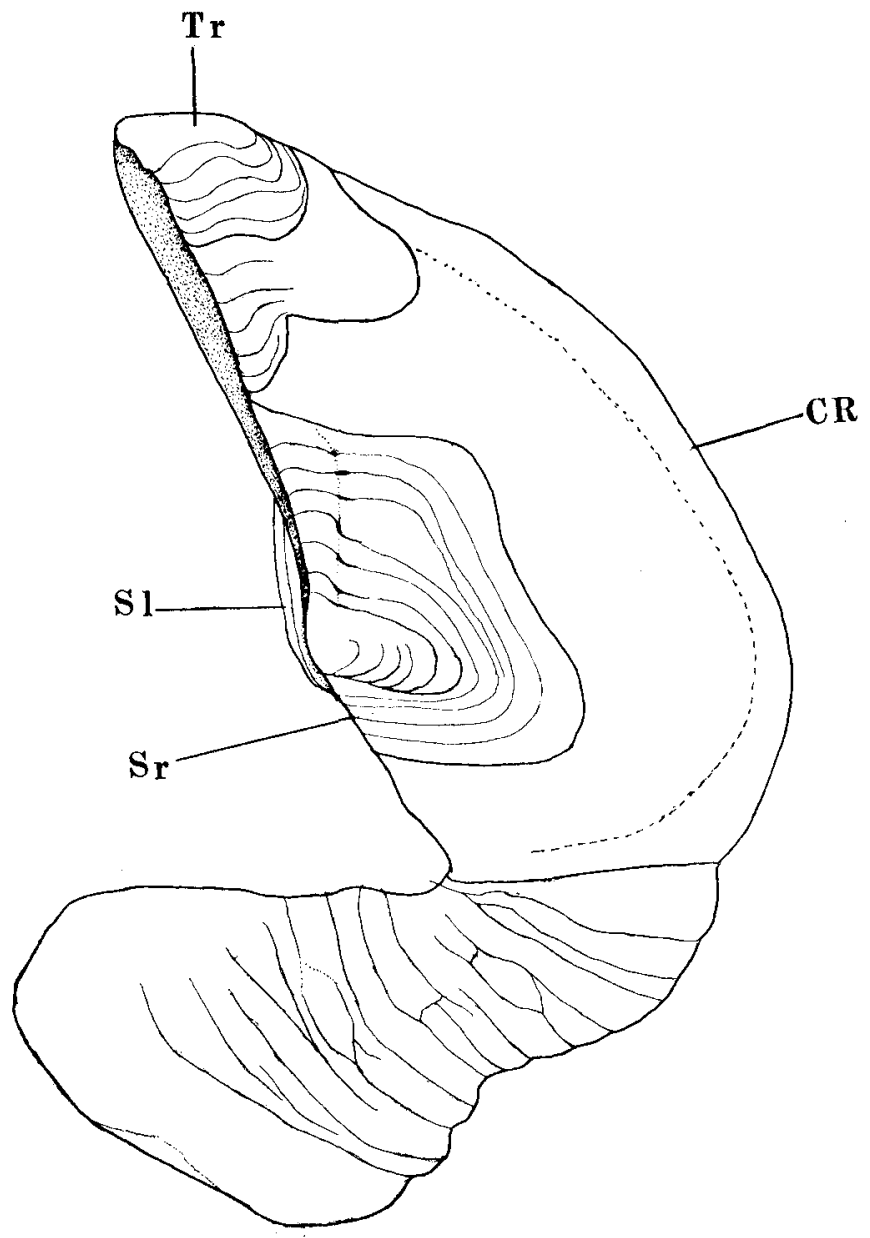

Fig. 8. Pagurolepas conchicola Stubings. Inner right side. $\mathrm{CR}$, carinal ridge; $\mathrm{S} 1$, left scutum; $\mathrm{Sr}$, right scutum; $\mathrm{Tr}$, right tergum. Dotted line indicates the inner wall of the mantle on the carinal side. $\times 6.6$ (approx.).

carinal border it is shortly forked about midway, but on the right margin towards the naked lateral surface it is strongly forked at base; the straight main part is broadly lanceolate and its lower elevated narrow area is well calcified and whitish; the umbo is exactly basal. The remaining upper broad area is only weakly calcified and 
concentrically annulated; this area may be imbedded in the integument, so that it may escape notice at a glance.

The scutum on the right side (Fig. 8, Sr) is larger than that on the left side (Figs. 7 and $8, \mathrm{Sl}$ ) and quadrangular in outline, the umbo being subcentral. The scutum on the outer left side is situated in a hollow surrounded by a ring-like folding of the integument; its outline is rather oval in a reduced form of the right scutum, with a small apical branch and a subcentral umbo. Its surrounding is sunken and apparently not calcified.

The tergum situated near the apex is rather rudimentary and saddle-shaped. The right one (Fig. 8, Tr) is a little larger than the left one (Fig. 7, Tl). The upper umbonal area on both sides is thickly calcified and whitish, while the lower marginal area is weakly calcified and scarcely annulated or unannulated.

The integument of the capitulum is thick and smooth on surface.

The peduncle is more rigid, cylindrical and expanded at the attachment base (Fig. 7, B). Its surface is irregularly annulated.

The mouthparts agree well with StubBings' description and figures.

The cirri have been damaged in the dissected specimen, most of the posterior rami being missing. But as far as could be detected, the pedicel of the cirri is well developed, rather bullate and consists of 2 segments (Fig. 9A). The rami are, however, very short, rather degenerative and consist of 4 segments only, each of which is adorned with fine fibroid setae in clusters at the distal ends of both curvatures, like Temnaspis and Alepas. The setation in the cirri thus corresponds to the lasiopod type, proposed originally by Pilsbry (1911) and later emphasized by NEwman et al. (1969).

The caudal appendage (Fig. 9B) is a uniarticulate blade bearing a cluster of long setae terminally.

Dimensions. - Length of capitulum $12 \mathrm{~mm}$ (approx.). Width of capitulum $6 \mathrm{~mm}$. Thickness of capitulum $2.5 \mathrm{~mm}$. Length of peduncle $12 \mathrm{~mm}$ (approx.). Diameter of peduncle $4 \mathrm{~mm}$.

Affinity.-As shown in the measurement, the present specimen is somewhat older than Stubbings' specimen from Zanzibar area, East Africa (John Murray Expedition station 122, $732 \mathrm{~m}$ ).

As pointed out by Stubbings (1940, p. 387), it is rather difficult to place $\mathrm{Pa}$ gurolepas in any existing families of the Lepadomorpha. Indeed, recent authors treat it only as "incerta sedis", as in the cases of Microlepas Hown (1907) and Rhizolepas Day (1939) (cf. KRüger, 1940, p. 449; Newman et al., 1969, p. R281).

The brush-like setation in the short rami is mainly responsible for filtering out the faecal material or food-debris ejected by the hermit crab commensally inhabiting together in the host gastropod shell upon which the barnacle feeds. Long setae located on the ventral margin of the pedicels may also assist in the filtration process. The mouthparts, which principally suggest differences in feeding habit and thus are 
of considerable systematic value, seem to resemble those of the Poecilasmatidae most nearly.

In concluding, Pagurolepas is never so specialized as Koleolepas and Malacolepas systematically, although they are similarly associated with the living Molluscan shells in life (cf. Hrro, 1933, 1937). So, it seems better to include this genus into the Poecilasmatidae rather than to establish a separate family for this genus alone.

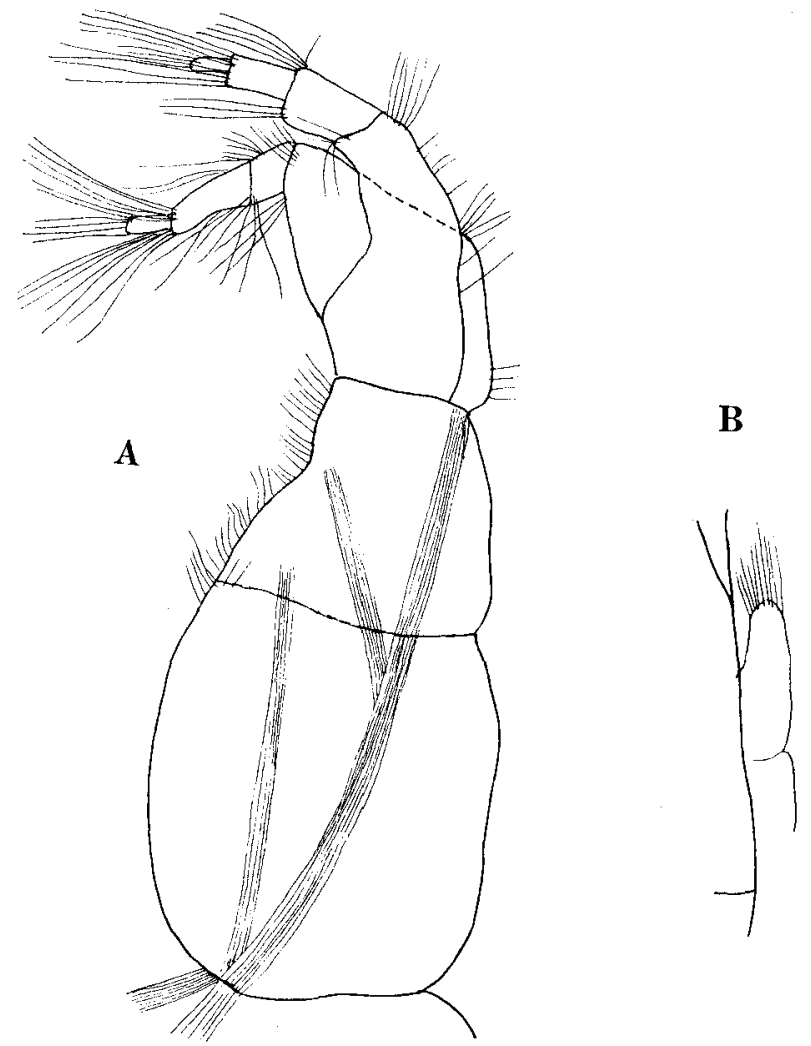

Fig. 9. Pagurolepas conchicola StubBings.

A, Third cirrus on the right side; $B$, caudal appendage. $\times 30$.

Other Associate.-In the vicinity of the Amakusa Islands, an Acrothoracican cirriped Trypetesa habei UTINOMI is also occasionally found in large-sized gastropod shells inhabited by hermit crabs, burrowing into the columella (UTINomI, 1964).

\section{REFERENGES}

Annandale, N. 1909. An account of the Indian Cirripedia Pedunculata. Part. Family Lepadidae. Mem. Ind. Mus., 2: 61-138, pls. VI-VII.

Aurivill.uUs, G.W.S. 1894. Studien über Girripedien. K. Svenska Vetensk. Akad. Handl., 26 (7): 1-89, pls. I-IX. 
Broch, Hj. 1922. Papers from Dr. Th. Mortensen's Pacific Expedition 1914-16. X. Studies on Pacific cirripeds. Vidensk. Medd. fra Dansk naturh. Foren., 73: 215-359.

1931. Papers from Dr. Th. Mortensen's Pacific Expedition 1914-16. LVI. Indomalayan Cirripedia. Ibid., 91: 1-146.

Darwin, Ch. 1851. A monograph on the subclass Cirripedia. The Lepadidae; or pedunculated cirripedes. 400 pp., 10 pls. Ray Society Publ., London.

DAY, J.H. 1939. A new cirripede-parasite Rhizolepas annelidicola nov. gen. et sp. Proc. Linn. Soc. Lond., 151 (2) : 64-78.

Hrro, F. 1932. Report on the Japanese species of the genus Calantica (Cirripedia). Annot. Zool. Japon., 13 (5): 467-484, pl. 30.

- 1933. Notes on two interesting pedunculate cirripeds, Malacolepas conchicola n. gen. et sp. and Koleolepas avis (Hiro), with remarks on their systematic positions. Mem. Coll. Sci. Kyoto Imp. Univ., Ser. B, 8 (3) : 233-247, pls. VIII-IX.

- 1937. Studies on Cirripedian fauna of Japan. II. Girripeds found in the vicinity of the Seto Marine Biological Laboratory. Ibid., 12 (3): 385-478.

Hoek, P.P.C. 1907. The Cirripedia of the Siboga-Expedition. Pt. I. Cirripedia Pedunculata. SibogaExped., mon. 31a. xxv +128 pp., 10 pls. Leiden.

Krüger, P. 1940. Cirripedia. Bronn's Klassen und Ordnungen des Tierreichs, Bd. 5, Abt. 1, Buch 3. 560 pp. Leipzig.

Newman, W.A., Zullo, V.A. and T.H. Withers. 1969. Cirripedia. Treatise on Invertebrate paleontology, Part R, Arthropoda 4, vol, 1: R206-R295.

Nilsson-Canteld, C.A. 1921. Cirripedien Studien. Zur Kenntnis der Biologie, Anatomie und Systematik dieser Gruppe. Zool. Bidrag Uppsala, 7: 75-390, pls. I*-III*.

Pilsbry, H.A. 1907. The barnacles (Cirripedia) contained in the collections of the U.S. National Museum. U.S. Natl. Mus., Bull. 60: i-x, 1-122, pls. I-IX.

- 1911. Remarks on new cirripedes. Proc. Acad. Nat. Sci. Philadelphia, 63: 170-173.

Stubsings, H.G. 1940. Cirripedia (Additional Part). John Murray Exped. 1933-34. Sci. Rep., 7 (3): 383-399.

Utinomi, H. 1949. Further notes on cirripeds from the Ogasawara Islands. Pacif. Sci., 3 (1): 93-99.

_ 1956. On the so-called "Umi-utiwa", a peculiar flabellate gorgonacean, with notes on a syllidean polychaete commensal. Publ. Seto Mar. Biol. Lab., 5 (2): 243-250, pl. XXVII.

- 1958. A new stalked cirriped (Pisiscalpellum withersi n. gen. et n. sp.) from Sagami Bay and a discussion on its phylogeny. Jap. J. Zool., 12 (2): 113-122.

- 1962. Studies on the Cirripedian fauna of Japan. VIII. Thoracic cirripeds from western Kyusyu. Publ. Seto Mar. Biol. Lab., 10 (2) : 212-239.

- 1964. Studies on the Cirripedia Acrothoracica. V. Morphology of Trypetesa habei Utinomi. Ibid., 12 (2): 117-132, pls. II-IV.

and T. Kikuchi. 1966. Cirriped Crustacea. Fauna and Flora of the Sea around the Amakusa Marine Biological Laboratory, Pt. VI. 11 pp.

Zevina, G.B. 1968. New species of Lepadomorpha (Cirripedia Thoracica) from the Bay of Tonkin. Crustaceana, 15 (1): 35-40. 